University of Nebraska - Lincoln

DigitalCommons@University of Nebraska - Lincoln

\title{
Efficacy of Rodenticide Baits for the Control of Three Invasive Rodent Species in Hawaii
}

\author{
William C. Pitt \\ National Wildlife Research Center, will.pitt@aphis.usda.gov \\ Laura C. Driscoll \\ USDA, Wildlife Services \\ Robert T. Sugihara \\ USDA, Wildlife Services
}

Follow this and additional works at: https://digitalcommons.unl.edu/icwdm_usdanwrc

Pitt, William C.; Driscoll, Laura C.; and Sugihara, Robert T., "Efficacy of Rodenticide Baits for the Control of Three Invasive Rodent Species in Hawaii" (2011). USDA National Wildlife Research Center - Staff Publications. 1340.

https://digitalcommons.unl.edu/icwdm_usdanwrc/1340

This Article is brought to you for free and open access by the U.S. Department of Agriculture: Animal and Plant Health Inspection Service at DigitalCommons@University of Nebraska - Lincoln. It has been accepted for inclusion in USDA National Wildlife Research Center - Staff Publications by an authorized administrator of DigitalCommons@University of Nebraska - Lincoln. 


\title{
Efficacy of Rodenticide Baits for the Control of Three Invasive Rodent Species in Hawaii
}

\author{
William C. Pitt • Laura C. Driscoll • \\ Robert T. Sugihara
}

Received: 9 February 2010/Accepted: 24 May 2010/Published online: 16 June 2010

(C) US Government 2010

\begin{abstract}
We tested the efficacy and palatability of nine commercial rodenticide bait formulations on Polynesian rats (Rattus exulans), roof rats ( $R$. rattus), and house mice (Mus musculus). Efficacy varied by rodenticide tested and rodent species. Generally, rodenticides were more effective against mice than for either of the rat species, and mice tended to consume more rodenticide bait than the laboratory chow alternative food. Efficacy was generally highest for the second-generation anticoagulants tested; however, this varied across products and one-first-generation rodenticide had similar effectiveness. Bait acceptance (palatability) also varied both by rodenticide and by rodent species. Acceptance was the lowest for the acute rodenticides. Bait acceptance appeared to substantially affect the efficacy of rodenticides; materials that were not well accepted produced lower mortality rates. Rodenticide products currently registered for use in Hawaii performed less effectively in this study than other available products not yet registered. Although markets for rodent control products for use on islands are limited, there are advantages to having additional products registered for island use in agriculture, conservation, and public health.
\end{abstract}

The use of trade names or corporate designations is for identification purposes and does not constitute an official endorsement or recommendation by the authors or the U.S. Department of Agriculture.

W. C. Pitt $(\bowtie) \cdot$ L. C. Driscoll - R. T. Sugihara

USDA, Wildlife Services, National Wildlife Research Center,

Hawaii Field Station, P.O. Box 10880, Hilo, HI 96721, USA

e-mail: will.pitt@aphis.usda.gov
For several centuries, invasive rodents have decimated native flora and fauna in Hawaii and other areas of the Pacific Basin, have reduced agriculture production, and have threatened human health (Atkinson 1985; Tomich 1986). Although many rodenticides are commercially available nationally, few are available for use in Hawaii or have been tested with wild rodents commonly found in the Pacific (Jacobs 1994). Likewise, there is variability among rodent populations in effective levels of toxicity and genetic resistance to some materials has developed in situations where repeated use has selected for resistant genes (Ashton et al. 1987).

Rodenticides are typically distinguished by the mode or speed of action of the active ingredient into two main categories: acute or fast-acting materials and chronic or slow-acting materials. Different acute rodenticides work in different ways but typically result in animal death after a single feeding. Acute rodenticides include bromethalin, a neurotoxin, and zinc phosphide, which produces phosphine gas after ingestion (Cherry et al. 1982; Johnston et al. 2005). Anticoagulants work by preventing the blood from naturally clotting. Toxicity information in the technical literature is highly variable and differs among rodent species and even among laboratory strains (Ashton et al. 1987). Anticoagulants are further distinguished as first or second generation, depending on their general toxicity and when they were developed. First-generation anticoagulants, developed after World War II, typically require multiple feedings to result in mortality and include warfarin, diphacinone, chlorophacinone, coumatetralyl, and several other less common materials. Second-generation rodenticides were originally developed to respond to the discovery of genetic resistance to first-generation materials in some rodent populations (Drummond and Rennison 1973; Jackson and Kaukeinen 1972; Thijssen 1995). These 
second-generation rodenticides, which have a high affinity for vitamin $\mathrm{K}$ receptors, usually require only a single feeding to be effective and include brodifacoum, bromadialone, and difethialone (Pelz et al. 2005; Endepols et al. 2007). The use of any US Environmental Protection Agency (EPA)-registered rodenticide is restricted legally by what is labeled for a particular use. However, pursuit of new pesticide products or uses is often limited because most products have not been tested using wild rodents and managers are hesitant to attempt projects with other chemicals if only limited data are available. The efficacy of many commercially available products on wild roof rats (Rattus rattus), Polynesian rats ( $R$. exulans), and house mice (Mus musculus) is unknown. Further, the few products that have been used successfully have not been systematically tested in a common laboratory environment or compared to other available products (Swift 1998). However, rodenticide products vary according to relative palatability with different species and in different environments, speed and modes of action, and environmental and human health effects (Hadler and Buckle 1992; Howald et al. 2007; Linder and Joermann 2001; Park and Lecka 1982; Stone et al. 1999). Thus, a product appropriate for one application might not be appropriate for all. Limiting the pool of available products restricts a manager's ability to mitigate such effects and to plan and conduct effective programs. A major data gap is the effectiveness of these products on rats typically found on Pacific islands and a comparison of the effectiveness of the products available. State and federal pesticide registrations authorized by the US Federal Insecticide, Fungicide, and Rodenticide Act (FIFRA) are classified by intended use and by authorized users. The current status of rodenticide materials under several of these categories are summarized for Hawaii.

\section{Resource Protection}

Only two diphacinone bait products are available for use in Hawaii to protect native birds from rodent predation (the Ramik ${ }^{\circledR}$ Mini-Bar, EPA SLN No. HI-980005 and Diphacinone-50 Pelleted Rodenticide Bait, EPA Reg. No. 5622835). Another diphacinone formulation was withdrawn from the market in Hawaii in September 2005. Thus, if the only available products were to lose effectiveness, not be well accepted in areas with abundant food, or if some rodent populations were to show resistance to the active ingredient (Jackson and Kaukeinen 1972), resource managers would not have an available alternative. Furthermore, because maintenance of pesticide registrations might entail annual fees, the companies currently producing these products could stop or decrease production, focus or more profitable markets, or fail to renew their labels.
Island Conservation

During the last 15 years, efforts to eradicate rodents from islands have increased and numerous successful international eradications have been completed using commercially available rodenticides (Veitch and Clout 2002). Few projects have been completed in the United States, but several projects are now in various stages on Wake Atoll, Palmyra Atoll (Line Islands), Lehua Island (Hawaii), and Cocos Island (Guam). Eradication efforts have been completed on roof rats from Buck Island and several smaller islands in the US Virgin Islands (Witmer et al. 2007) and Mokolii Island (Hawaii; J. Murphy, USDA Wildlife Services, personal communication) using various diphacinone baits and on the three Anacapa Islands off the California coast using a brodifacoum product (Howald et al. 2005). An unsuccessful effort occurred on Palmyra Atoll using brodifacoum (J. Murphy, USDA Wildlife Services, personal communication). Witmer and colleagues found M. musculus populations irrupted on Buck Island following successful eradication of $R$. rattus, presumably because the use of diphacinone bait station arrays did not make bait fully available to all mice and because removal of rats released mouse activity and breeding that had been suppressed (Caut et al. 2007; Witmer et al. 2007). Several other island rodent eradication efforts (not well documented) in US territories might have been successful, but we have been unable to determine locations and results. Most international rodent eradication efforts have also used brodifacoum or diphacinone bait products and primarily relied on either preliminary field efficacy data or on tests with laboratory rats (Swift 1998; Witmer et al. 1998). Three rodenticide formulations have been registered recently for island use $(0.005 \%$ diphacinone and $0.0025 \%$ brodifacoum pellets for use in wet or dry conditions; EPA Registrations Nos. 56228-35, 56228-36, and 56228-37 respectively) to be used for broadcast application in conservation areas to manage or eliminate rats.

\section{Agriculture}

Only a few rodenticides are registered for use in Hawaii for traditional crops, such as sugarcane and macadamia nuts. There are no registrations for emerging agricultural crops, particularly tropical fruits. Currently, only a single diphacinone-based product is registered for use in agriculture (Special Local Need No. HI-980006) and its use is restricted to macadamia nut orchards. Zinc phosphide rodenticide remains available for agriculture uses in Hawaii under a federal registration for a concentrate to be prepared with grain baits (EPA Registration No. 56228-6). As a consequence of our results, reported here, two new chlorophacinone formulations were registered for use in 
Hawaii for protecting tropical nut and fruit orchards and for protecting corn and soybeans grown for seed (Special Local Need No. HI-080001 and HI-080002).

The diversification of Hawaiian agriculture related to major land-use changes associated with the decline of local sugar production has outpaced the development of new rodenticide labels. Additional materials should be evaluated for use in both new and traditional crops.

\section{Human Health and Safety}

Wild and commensal rodents are primary reservoirs for many diseases affecting both humans and domestic animals worldwide and effective rodent control with rodenticides is one of the important ways to reduce the risk of disease outbreaks. Hawaii, in particular, has been subject to historical outbreaks of rodent-borne bubonic plague and leptospirosis (Tomich 1986). Currently, only zinc phosphide oat bait is registered to control rodent outbreaks for human health in Hawaii (Special Local Need No. HI-010001). There is considerable human health risk with having only a single product registered because the product might not be available when needed or the product might not be effective for a particular situation.

\section{Objectives}

Effective rodenticide bait formulations are needed to control and eradicate rodents and, ideally, managers should have a variety of product options available for different uses or situations. Although many commercial rodenticide baits are available worldwide, there has been little recent laboratory efficacy testing with wild rodents, especially using one standardized protocol to allow comparisons. Additionally, rodents often have a choice of food items, so effective baits must be attractive and palatable, as well as efficacious when presented with an alternative food. In developing broadcast application uses, which is our primary area of interest in this article, there is a premium on using materials that can be delivered in a single application. Many first-generation anticoagulants (which generally had label recommendations for 2-3 weeks of exposure to the species of primary concern on Pacific islands) have fallen into disuse in favor of the second-generation materials or are no longer registered. Fall (1977, 1982) contended that any of the then available anticoagulants could be effectively used for these Asian species in the laborintensive, prolonged "sustained baiting method." Our problem has been to identify materials that can be effectively used in modern, mechanized approaches; these studies represent our initial step.

We used a general laboratory efficacy standard of at least $80 \%$ mortality of the animals in a test group
(Schneider and Hitch 1982, p. 309) in assigning animals in our trials. It is widely recognized that materials performing below such a standard in laboratory tests might often perform adequately under field conditions because of differences in relative palatability compared to alternative foods. For example, Fall (1982) noted that most grain-based bait materials were well accepted compared to the green, growing rice plants commonly damaged by rats in the Philippines. In this article, we report the results of a comprehensive laboratory study of the efficacy and palatability of nine commercial rodenticide bait formulations for Polynesian rats (Rattus exulans), roof rats ( $R$. rattus), and house mice (Mus musculus) wild-captured locally and maintained in our research facility in Hawaii, with the hope that additional registrations of rodenticides might be considered for conservation, agriculture, and public safety uses.

\section{Materials and Methods}

The study was conducted in three tiers, each depending on previous results. Tier 2 was only conducted depending on the outcome of the Tier 1 study. Tier 3 was only conducted depending on the outcome of the Tier 2 study.

Tier 1 Study: Three-Day Choice Trial with a Rodenticide Bait and Laboratory Rat Chow

Three days is the shortest period of time that rodenticide bait would typically be available to rodents under field conditions after a single broadcast-bait drop (allowing for weathering and bait consumption by invertebrates such as crabs). The results could help determine materials selected for operational control and eradication programs.

\section{Tier 2 Study: Seven-Day Choice Trial} with a Rodenticide Bait and Laboratory Rat Chow

This study was only conducted if the mortality among subjects in the Tier 1 test for a particular formulation was less than $80 \%$. The results help to determine whether increasing the bait amount in an initial field application or using a second bait application might increase the mortality rate of rodents in operational programs.

Tier 3 Study: Seven-Day No-Choice Trial with Only Rodenticide Bait Available

This study was only conducted when mortality among the Tier 2 subjects was less than $80 \%$. The results help to determine if bait palatability relative to the alternative food is a problem or if testing for rodenticide resistance might be 
warranted (Drummond and Rennison 1973; Pelz et al. 1995).

Test Subjects, Data Collection, and Analysis

Free-ranging wild rodents were live-trapped near Hilo, Hawaii in areas where, to our knowledge, there had been no use of rodenticides in recent years. Test animals included 165 R. exulans, $160 \mathrm{R}$. rattus, and $130 \mathrm{M}$. musculus. Animals were maintained in individual rack cages and provided commercial laboratory rodent chow (5001 Rodent Diet; PMI Nutrition International, Brentwood, MO) and water ad libitum. Ambient laboratory conditions ranged between $24^{\circ} \mathrm{C}$ and $26^{\circ} \mathrm{C}$, with ventilation by circulated air-conditioned fresh air, and a 12-h/12-h light/dark cycle. Animals were allowed at least 3 days to acclimate to these conditions and were weighed and sexed within 1 day before testing.

All rodents were examined at least once daily; food or bait consumption, animal condition, and mortalities were recorded. If an animal appeared to be experiencing excessive pain or distress or if death appeared imminent, it could be euthanized under our protocol; this provision was only necessary in one instance as noted in Table 1. Dead rodents were labeled in individual zip-lock bags and refrigerated for necropsy. During necropsy, animals were weighed, sexed, and examined for signs of rodenticide toxicosis, following the protocol in Stone et al. (1999) for animals exposed to anticoagulants. Surviving rodents were maintained on the laboratory diet and water for 10 days after testing and then were euthanized and necropsied. Any mortality that occurred in the 10-day postexposure observation period was recorded and ascribed to the test procedures.

Rodents were randomly assigned to treatment and reference groups using the random-number generator program RANDSEL (Sugihara 1997). The percents mortality of treatment and reference groups were examined with $\chi^{2}$ contingency tests. The food consumption by groups was expressed as percent bait acceptance (bait consumption/ total food consumption $\times 100)$ and examined by multiple analysis of variance (ANOVA) tests. The pretrial and posttrial weights of groups were also examined by a multiple ANOVA.

On day 1 of each 3-day choice trial (Tier 1 ), 10 caged rodents were randomly assigned to each of 9 treatments (0.005\% diphacinone; $0.0025 \%$ brodifacoum; $0.005 \%$ bromadialone; $0.005 \%$ chlorophacinone, $0.0025 \%$ difethialone, $0.01 \%$ bromethalin, $2 \%$ zinc phosphide -2 different formulations-and $0.025 \%$ warfarin); another 5 animals were assigned as a reference group. Each chemical was tested on each of the three rodent species. All rodents were at least 2 months of age and sexually mature. Each treatment group had two to three females, the remainder being males. If sufficient gender numbers were not captured, deviations from this ratio were restricted to the reference groups, which received only laboratory rodent chow and water during the treatment and observation periods.

Each animal in the treatment groups was provided with laboratory chow and water, ad libitum, and an excess of rodenticide bait. Bait and chow were replenished as needed so that rodents always had both freely available. Food consumption was determined by weighing food at treatment initiation and whenever it was replenished and then correcting for remaining food and spillage on cage trays after the trial. The Tier 2 studies, if needed, were conducted with separate groups of rodents (five animals per group). This trial was performed as described, with the exception that rodenticide bait was provided for 7 days before commencing the 10-day observation period. Tier 3 studies (also with separate groups) were only conducted if mortality in a Tier 2 group was less than $80 \%$ after treatment and observation. Procedures were similar, except that no alternative food was offered in addition to the bait formulation during the 7-day exposure period.

\section{Results}

Efficacy and palatability for the nine rodenticide formulations varied by the rodent species and by the rodenticide tested. Generally, the rodenticides were more effective against mice than either of the rat species, and mice tended to eat more rodenticide bait than laboratory chow. However, some rodenticides were not effective against mice, even in the no choice tests.

\section{Tier 1}

Only 12 of the 27 rodenticide trials resulted in greater than $80 \%$ mortality from a 3-day exposure. The highest mortality rates were found with the second-generation anticoagulants (Table 1). The only rodenticide formulation that had $80 \%$ or higher mortality for all three species was a difethialone-based rodenticide. Rodenticide baits containing either bromadialone or brodifacoum had $70 \%$ or higher mortality rates for all three rodent species. Two bait formulations containing either warfarin or diphacinone had mortality rates of $40 \%$ or less for all rodent species tested in the 3-day choice trial.

Palatability varied greatly among products (Table 1). The chlorophacinone bait product was notable in having high acceptance by all three rodent species, although mortality percentages were below $80 \%$ for $R$. rattus and M. musculus. Although actual amounts varied, all species 
Table 1 Species, treatment, mortality, mean body weight, mean bait consumption, and bait acceptance of M. musculus, R. exulans, and R. rattus exposed to nine different rodenticides and associated reference diets (Tier 1)

\begin{tabular}{|c|c|c|c|c|c|c|c|}
\hline Species & Bait treatment & $\begin{array}{l}\text { Mortality } \\
(\%)\end{array}$ & $\begin{array}{l}\text { Mortality } \\
(n)\end{array}$ & $\begin{array}{l}\text { Mortality } \\
\text { range (days) }\end{array}$ & $\begin{array}{l}\text { Mean body } \\
\text { weight }(\mathrm{g})\end{array}$ & $\begin{array}{l}\text { Mean bait } \\
\text { consumption }(\mathrm{g})\end{array}$ & $\begin{array}{l}\text { Bait } \\
\text { acceptance }^{a}(\%)\end{array}$ \\
\hline \multicolumn{8}{|c|}{ Mus musculus } \\
\hline & \multirow[t]{2}{*}{ Generation ${ }^{\circledR}$ difethialone } & \multirow[t]{2}{*}{80} & Yes (8) & $5-13$ & 13.3 & 9.4 & 85.6 \\
\hline & & & No (2) & 0 & 16.2 & 10.4 & 86.1 \\
\hline & Gunslinger ${ }^{\circledR}$ bromethalin & 100 & Yes $(10)$ & $1-3$ & 16.3 & 1.0 & 63.7 \\
\hline & Havoc $\AA$ brodifacoum & 100 & Yes $(10)$ & $5-11$ & 13.6 & 9.5 & 77.4 \\
\hline & \multirow[t]{2}{*}{ Maki ${ }^{\circledR}$ bromadiolone } & \multirow[t]{2}{*}{90} & Yes (9) & $4-12$ & 15.1 & 9.8 & 76.1 \\
\hline & & & No (1) & 0 & 15.8 & 1.3 & 10.7 \\
\hline & \multirow[t]{2}{*}{ Adios ${ }^{\circledR}$ Mouse Killer warfarin } & \multirow[t]{2}{*}{40} & Yes (4) & $4-6$ & 15.3 & 6.7 & 67.1 \\
\hline & & & No (6) & 0 & 14.2 & 7.7 & 68.0 \\
\hline & \multirow[t]{2}{*}{ Ramik Green ${ }^{\circledR}$ diphacinone } & \multirow[t]{2}{*}{30} & Yes (3) & $3-4$ & 13.3 & 11.0 & 84.0 \\
\hline & & & No (7) & 0 & 15.0 & 9.7 & 64.3 \\
\hline & \multirow[t]{2}{*}{ Rozol ${ }^{\circledR}$ chlorophacinone } & \multirow[t]{2}{*}{50} & Yes (5) & $3-5$ & 15.0 & 8.6 & 85.2 \\
\hline & & & No (5) & 0 & 13.4 & 9.6 & 84.9 \\
\hline & Prozap ${ }^{\circledR}$ zinc phosphide oat & 100 & Yes $(10)$ & $1-10$ & 14.6 & 0.4 & 63.7 \\
\hline & \multirow[t]{2}{*}{ Prozap ${ }^{\circledR}$ zinc phosphide pellet } & \multirow[t]{2}{*}{90} & Yes (9) & $1-10$ & 14.5 & 1.6 & 48.9 \\
\hline & & & No (1) & 0 & 15.9 & 2.0 & 25.4 \\
\hline & Reference (laboratory chow) & 0 & No (15) & 0 & 14.4 & NA & NA \\
\hline \multicolumn{8}{|c|}{ Rattus exulans } \\
\hline & \multirow[t]{2}{*}{ Generation ${ }^{\circledR}$ difethialone } & \multirow[t]{2}{*}{90} & Yes (9) & $3-9$ & 63.2 & 13.3 & 71.1 \\
\hline & & & No (1) & 0 & 43.0 & 1.4 & 10.5 \\
\hline & \multirow[t]{2}{*}{ Gunslinger ${ }^{\circledR}$ bromethalin } & \multirow[t]{2}{*}{80} & Yes (16) & $1-3$ & 51.3 & 3.1 & 48.6 \\
\hline & & & No (4) & 0 & 63.8 & 1.2 & 7.5 \\
\hline & \multirow[t]{2}{*}{ Havoc $\AA$ brodifacoum } & \multirow[t]{2}{*}{70} & Yes (7) & $4-8$ & 55.7 & 15.7 & 64.1 \\
\hline & & & No (3) & 0 & 67.3 & 1.8 & 12.4 \\
\hline & \multirow[t]{2}{*}{ Maki ${ }^{\circledR}$ bromadiolone } & \multirow[t]{2}{*}{70} & Yes (7) & $4-8$ & 57.5 & 16.4 & 67.5 \\
\hline & & & No (3) & 0 & 65.7 & 9.0 & 34.0 \\
\hline & Adios ${ }^{\circledR}$ Mouse Killer warfarin & 30 & Yes (3) & $4-8$ & 53.3 & 14.7 & 61.0 \\
\hline & & & No (7) & 0 & 60.6 & 4.2 & 12.7 \\
\hline & Ramik Green ${ }^{\circledR}$ diphacinone & 20 & Yes (2) & 6 & 47.0 & 11.8 & 53.6 \\
\hline & & & No $(8)$ & 0 & 58.3 & 9.9 & 49.9 \\
\hline & Rozol ${ }^{\circledR}$ chlorophacinone & 80 & Yes (8) & $3-7$ & 59.7 & 17.2 & 85.4 \\
\hline & & & No (2) & 0 & 58.5 & 17.1 & 80.5 \\
\hline & Prozap ${ }^{\circledR}$ zinc phosphide oat & 70 & Yes (7) & $1-3$ & 47.4 & 1.6 & 36.5 \\
\hline & & & No (3) & 0 & 59.7 & 2.4 & 11.4 \\
\hline & Prozap ${ }^{\circledR}$ zinc phosphide pellet & 20 & Yes (2) & 1 & 43.0 & 2.2 & 42.9 \\
\hline & & & No (8) & 0 & 53.1 & 2.9 & 14.6 \\
\hline & Reference (laboratory chow) & 0 & No (15) & 0 & 52.9 & NA & NA \\
\hline Rattus $r$ & & & & & & & \\
\hline & Generation ${ }^{\circledR}$ difethialone & 90 & Yes (9) & $4-10$ & 138.2 & 31.5 & 74.8 \\
\hline & & & No (1) & 0 & 90.0 & 30.3 & 88.3 \\
\hline & Gunslinger ${ }^{\circledR}$ bromethalin & 20 & Yes (2) ${ }^{b}$ & 3 & 134.0 & 5.8 & 37.0 \\
\hline & & & No $(8)$ & 0 & 133.8 & 4.6 & 33.6 \\
\hline & Havoc $\AA$ brodifacoum & 90 & Yes (9) & $4-9$ & 134.7 & 35.1 & 77.2 \\
\hline & & & No (1) & 0 & 148.0 & 39.9 & 84.4 \\
\hline & Maki ${ }^{\circledR}$ bromadiolone & 90 & Yes (9) & $4-13$ & 127.2 & 34.7 & 81.5 \\
\hline & & & No (1) & 0 & 154.0 & 26.7 & 68.0 \\
\hline
\end{tabular}


Table 1 continued

\begin{tabular}{|c|c|c|c|c|c|c|c|}
\hline Species & Bait treatment & $\begin{array}{l}\text { Mortality } \\
(\%)\end{array}$ & $\begin{array}{l}\text { Mortality } \\
(n)\end{array}$ & $\begin{array}{l}\text { Mortality } \\
\text { range (days) }\end{array}$ & $\begin{array}{l}\text { Mean body } \\
\text { weight ( } \mathrm{g} \text { ) }\end{array}$ & $\begin{array}{l}\text { Mean bait } \\
\text { consumption }(\mathrm{g})\end{array}$ & $\begin{array}{l}\text { Bait } \\
\text { acceptance }^{\mathrm{a}}(\%)\end{array}$ \\
\hline & \multirow[t]{2}{*}{ Adios ${ }^{\circledR}$ Mouse Killer warfarin } & \multirow[t]{2}{*}{20} & Yes (2) & $4-6$ & 135.0 & 31.4 & 57.0 \\
\hline & & & No $(8)$ & 0 & 151.2 & 12.3 & 23.4 \\
\hline & \multirow[t]{2}{*}{ Ramik Green ${ }^{\circledR}$ diphacinone } & \multirow[t]{2}{*}{40} & Yes (4) & $7-11$ & 173.0 & 25.6 & 72.3 \\
\hline & & & No (6) & 0 & 153.7 & 22.5 & 60.3 \\
\hline & \multirow[t]{2}{*}{ Rozol® chlorophacinone } & \multirow[t]{2}{*}{50} & Yes (5) & $4-7$ & 166.8 & 27.5 & 81.5 \\
\hline & & & No (5) & 0 & 154.4 & 26.1 & 72.6 \\
\hline & \multirow[t]{2}{*}{ Prozap ${ }^{\circledR}$ zinc phosphide oat } & \multirow[t]{2}{*}{10} & Yes (1) & 1 & 251.0 & 2.2 & 18.1 \\
\hline & & & No (9) & 0 & 171.2 & 1.8 & 5.6 \\
\hline & \multirow[t]{2}{*}{ Prozap ${ }^{\circledR}$ zinc phosphide pellet } & \multirow[t]{2}{*}{20} & Yes (2) & 2 & 109.0 & 2.6 & 23.4 \\
\hline & & & No $(8)$ & 0 & 155.0 & 2.4 & 8.2 \\
\hline & Reference (laboratory chow) & 0 & No & 0 & 129.4 & NA & NA \\
\hline
\end{tabular}

Note: Animals were offered rodenticide bait and laboratory chow for 3 days; then the rodenticides were removed and laboratory chow was provided ad libitum for an additional 10-day observation period

${ }^{\text {a }}$ Bait acceptance $=($ Bait consumption/Total food consumption $) \times 100$

b Animal was moribund and euthanized

ate more than six times as much of the chlorophacinone bait as of the alternative food in the 3-day choice trial. Warfarin bait, zinc phosphide pellets, zinc phosphide oats, and the bromethalin-based product were generally not well accepted by the two rat species but were eaten by mice. In general, mice ate more poison bait over the laboratory chow with most materials.

\section{Tier 2}

For the 7-day choice series, we conducted 15 trials. As expected, mortality rates were highest for materials that were well accepted. The two zinc phosphide products and the warfarin product had relatively low acceptance; nonetheless, $R$. rattus mortality was $80 \%$ for both the warfarin and zinc phosphide oat products. Only the product containing diphacinone did not achieve $80 \%$ or higher mortality for at least one of the three rodent species. The warfarin product (M. musculus) and zinc phosphide pellets (R. exulans and R. rattus) had mortality rates less than $20 \%$ with one or more species. The only active ingredients that achieved $80 \%$ or greater mortality in the choice tests (Tables 1,2) with at least one species were chlorophacinone, brodifacoum, bromadiolone, bromethalin, difethialone, and warfarin. The chlorophacinone product had produced $80 \%$ mortality with $R$. exulans in the Tier 1 series and produced $100 \%$ mortality for the two species tested in this series ( $R$. rattus and M. musculus). The difethialone, bromethalin, brodifacoum, bromadialone, and diphacinone products were relatively well accepted by at least one species, but only the chlorophacinone bait product was well accepted by all three.
Tier 3

In the no-choice tests (Table 3), only three trials did not achieve $80 \%$ mortality: the diphacinone bait and the warfarin bait on M. musculus (both 40\%) and the zinc phosphide pellet formulation on $R$. exulans $(60 \%)$. All three bait products evaluated for $R$. rattus in this series (bromethalin, diphacinone, and zinc phosphide pellets) produced $100 \%$ mortality. Rodents tended to consume lesser bait amounts of the faster acting materials: bromethalin, zinc phosphide oat, and zinc phosphide pellet; however, mortality for animals tested with these materials in this tier was above $80 \%$, except for zinc phosphide pellets with $R$. exulans. The relatively lower consumption of the warfarin and diphacinone materials compared to laboratory chow consumption by reference groups could indicate a palatability problem that might warrant further examination.

\section{Discussion}

The efficacy of any product is a combination of the toxicity of the rodenticide itself, the relative palatability to the target species under use conditions, the method of bait application or presentation, and numerous other factors. In field studies by Quy et al. (1996), the method of bait application was of overriding importance for field effectiveness with alternative foods available.

Although laboratory testing is an important first step in predicting the effectiveness of rodenticides or bait formulations for particular rodent species and has been generally a required step in the registration process, 
Table 2 Species, treatment, mortality, mean body weight, mean bait consumption, and bait acceptance of M. musculus, R. exulans, and R. rattus exposed to up to six different rodenticides and associated reference diets (Tier 2)

\begin{tabular}{|c|c|c|c|c|c|c|c|}
\hline Species & Bait treatment & $\begin{array}{l}\text { Mortality } \\
(\%)\end{array}$ & $\begin{array}{l}\text { Mortality } \\
(n)\end{array}$ & $\begin{array}{l}\text { Mortality } \\
\text { range (days) }\end{array}$ & $\begin{array}{l}\text { Mean body } \\
\text { weight }(\mathrm{g})\end{array}$ & $\begin{array}{l}\text { Mean bait } \\
\text { consumption }(\mathrm{g})\end{array}$ & $\begin{array}{l}\text { Bait } \\
\text { acceptance }^{a}(\%)\end{array}$ \\
\hline \multicolumn{8}{|c|}{ Mus musculus } \\
\hline & \multirow[t]{2}{*}{ Adios ${ }^{\circledR}$ Mouse Killer warfarin } & \multirow[t]{2}{*}{20} & Yes (1) & 7 & 10.9 & 12.6 & 72.4 \\
\hline & & & No (4) & 0 & 13.5 & 16.4 & 77.1 \\
\hline & \multirow[t]{2}{*}{ Ramik Green ${ }^{\circledR}$ diphacinone } & \multirow[t]{2}{*}{25} & Yes (1) & 8 & 13.2 & 13.0 & 82.9 \\
\hline & & & No $\left(3^{b}\right)$ & 0 & 13.2 & 7.9 & 38.5 \\
\hline & Rozol® chlorophacinone & 100 & Yes (5) & $8-9$ & 13.3 & 11.6 & 68.3 \\
\hline & Reference (laboratory chow) & 0 & No (5) & 0 & 12.5 & NA & NA \\
\hline \multicolumn{8}{|c|}{ Rattus exulans } \\
\hline & Havoc $\AA$ brodifacoum & 100 & Yes (5) & $4-9$ & 61.4 & 28.1 & 83.2 \\
\hline & Maki ${ }^{\circledR}$ bromadiolone & 100 & Yes (5) & $3-10$ & 66.8 & 22.9 & 80.1 \\
\hline & \multirow[t]{2}{*}{ Adios ${ }^{\circledR}$ Mouse Killer warfarin } & \multirow[t]{2}{*}{60} & Yes (3) & $6-8$ & 66.0 & 14.9 & 34.4 \\
\hline & & & No (2) & 0 & 60.0 & 10.9 & 28.1 \\
\hline & \multirow[t]{2}{*}{ Ramik Green ${ }^{\circledR}$ diphacinone } & \multirow[t]{2}{*}{40} & Yes (2) & $3-6$ & 72.0 & 25.5 & 73.9 \\
\hline & & & No (3) & 0 & 57.7 & 7.5 & 18.0 \\
\hline & \multirow[t]{2}{*}{ Prozap ${ }^{\circledR}$ zinc phosphide oat } & \multirow[t]{2}{*}{60} & Yes (3) & $2-4$ & 54.7 & 1.8 & 19.9 \\
\hline & & & No (2) & 0 & 67.0 & 2.4 & 5.1 \\
\hline & Prozap ${ }^{\circledR}$ zinc phosphide pellet & 0 & No (5) & 0 & 60.4 & 3.5 & 5.7 \\
\hline & Reference (laboratory chow) & 0 & No (5) & 0 & 59.8 & NA & NA \\
\hline \multicolumn{8}{|c|}{ Rattus rattus } \\
\hline & \multirow[t]{2}{*}{ Adios ${ }^{\circledR}$ Mouse Killer warfarin } & \multirow[t]{2}{*}{80} & Yes (4) & $4-8$ & 174.5 & 33.9 & 56.5 \\
\hline & & & No (1) & 0 & 205.0 & 34.5 & 36.1 \\
\hline & \multirow[t]{2}{*}{ Gunslinger ${ }^{\circledR}$ bromethalin } & \multirow[t]{2}{*}{60} & Yes (3) & $2-3$ & 181.0 & 8.6 & 29.2 \\
\hline & & & No (2) & 0 & 125.5 & 8.5 & 10.9 \\
\hline & \multirow[t]{2}{*}{ Ramik Green ${ }^{\circledR}$ diphacinone } & \multirow[t]{2}{*}{60} & Yes (3) & 0 & 155.7 & 71.6 & 74.1 \\
\hline & & & No (2) & $4-7$ & 139.0 & 5.5 & 4.6 \\
\hline & Rozol ${ }^{\circledR}$ chlorophacinone & 100 & Yes (5) & $5-9$ & 182.2 & 69.1 & 92.1 \\
\hline & \multirow[t]{2}{*}{ Prozap ${ }^{\circledR}$ zinc phosphide oat } & \multirow[t]{2}{*}{80} & Yes (4) & $1-2$ & 143.8 & 3.0 & 18.5 \\
\hline & & & No (1) & 0 & 142.0 & 4.8 & 4.5 \\
\hline & \multirow[t]{2}{*}{ Prozap ${ }^{\circledR}$ zinc phosphide pellet } & \multirow[t]{2}{*}{20} & Yes (1) & 4 & 124.0 & 3.6 & 7.1 \\
\hline & & & No (4) & 0 & 142.0 & 3.6 & 4.0 \\
\hline & Reference (laboratory chow) & 0 & No (10) & 0 & 159.9 & NA & NA \\
\hline
\end{tabular}

Note: Animals were offered rodenticide bait and laboratory chow for 7 days; then the rodenticides were removed and laboratory chow was provided ad libitum for an additional 10-day observation period

${ }^{\mathrm{a}}$ Bait acceptance $=($ Bait consumption/Total food consumption $) \times 100$

b One mouse was accidentally killed and was excluded from analysis

materials that show poor performance in laboratory tests might often perform very effectively under some field conditions. For example, the diphacinone formulation we studied had mortalities below $80 \%$ for all three species in both the 3-day and 7-day choice tests. However, Swift (1998), using the same diphacinone product in 1998Ramik Green-found satisfactory laboratory performance and recommended field testing. A similar $0.005 \%$ diphacinone formulation performed very satisfactorily in the field to control $R$. rattus in the Virgin Islands (Witmer et al. 1998, 2007) and in Hawaii (Spurr et al. 2003). However, Witmer et al. (2007) subsequently reported the formulation with a hand-broadcast application method they used was ineffective for house mouse control (a nontarget species in their rat eradication project). Given the current importance of diphacinone as one of the few registered rodenticides in Hawaii, further research to understand and improve these results and to develop additional product formulations are probably warranted. 
Table 3 Species, treatment, mortality, mean body weight, mean bait consumption, and bait acceptance of M. musculus, R. exulans, and R. rattus exposed to up to four different rodenticides and associated reference diets (Tier 3)

\begin{tabular}{|c|c|c|c|c|c|c|}
\hline Species & Bait treatment & $\begin{array}{l}\text { Mortality } \\
(\%)\end{array}$ & $\begin{array}{l}\text { Mortality } \\
(n)\end{array}$ & $\begin{array}{l}\text { Mortality } \\
\text { range (days) }\end{array}$ & $\begin{array}{l}\text { Mean body } \\
\text { weight }(g)\end{array}$ & $\begin{array}{l}\text { Mean bait } \\
\text { consumption }^{\mathrm{a}}(\mathrm{g})\end{array}$ \\
\hline \multirow[t]{5}{*}{ Mus musculus } & \multirow[t]{2}{*}{ Adios ${ }^{\circledR}$ Mouse Killer warfarin } & \multirow[t]{2}{*}{40} & Yes (2) & $5-8$ & 13.8 & 16.4 \\
\hline & & & No (3) & 0 & 13.5 & 16.3 \\
\hline & \multirow[t]{2}{*}{ Ramik Green ${ }^{\circledR}$ diphacinone } & \multirow[t]{2}{*}{40} & Yes (2) & 6 & 14.0 & 19.0 \\
\hline & & & No (3) & 0 & 14.2 & 19.9 \\
\hline & Reference (laboratory chow) & 0 & No $\left(4^{\mathrm{b}}\right)$ & 0 & 13.2 & NA \\
\hline \multirow[t]{8}{*}{ Rattus exulans } & \multirow[t]{2}{*}{ Adios ${ }^{\circledR}$ Mouse Killer warfarin } & \multirow[t]{2}{*}{80} & Yes (4) & $4-6$ & 73.8 & 23.6 \\
\hline & & & No (1) & 0 & 66.7 & 28.6 \\
\hline & Ramik Green ${ }^{\circledR}$ diphacinone & 100 & Yes (5) & $5-8$ & 67.4 & 31.0 \\
\hline & \multirow[t]{2}{*}{ Prozap ${ }^{\circledR}$ zinc phosphide oat } & \multirow[t]{2}{*}{80} & Yes (4) & $1-7$ & 62.7 & 2.1 \\
\hline & & & No (1) & 0 & 82.0 & 3.3 \\
\hline & \multirow[t]{2}{*}{ Prozap ${ }^{\circledR}$ zinc phosphide pellet } & \multirow[t]{2}{*}{60} & Yes (3) & 1 & 60.0 & 2.1 \\
\hline & & & No (2) & 0 & 82.1 & 3.6 \\
\hline & Reference (laboratory chow) & 0 & No (5) & 0 & 73.1 & NA \\
\hline \multirow[t]{4}{*}{ Rattus rattus } & Gunslinger ${ }^{\circledR}$ bromethalin & 100 & Yes (5) & $1-2$ & 142.2 & 7.0 \\
\hline & Ramik Green ${ }^{\circledR}$ diphacinone & 100 & Yes (5) & $6-10$ & 147.4 & 86.9 \\
\hline & Prozap ${ }^{\circledR}$ zinc phosphide pellet & 100 & Yes (5) & $1-5$ & 150.6 & 3.1 \\
\hline & Reference (laboratory chow) & 0 & No & 0 & 159.6 & NA \\
\hline
\end{tabular}

Note: Animals were offered rodenticide bait for 7 days; then the rodenticides were removed and laboratory chow was provided ad libitum for an additional 10-day observation period

${ }^{\text {a }}$ The Tier 3 protocol provided no alternative food choice

${ }^{\mathrm{b}}$ One mouse was accidentally killed and was excluded from analysis

\section{Rodenticide Categories}

As expected, the newer, second-generation anticoagulants generally performed better with these rodent species than the first-generation anticoagulants or the acute rodenticides. Nonetheless, in addition to efficacy, a manager's choice of rodenticide for a specific application needs to include an overall risk assessment of the potential for primary and secondary hazards and of overall safety under operational conditions. Second-generation anticoagulant rodenticides are generally more toxic than the first-generation materials and, in some cases, present more serious health and environmental concerns. In this regard, new restrictions have recently been added to the use of the use of 10 common rodenticides, particularly restricting uses of second-generation rodenticides (EPA 2008).

In our study, second-generation anticoagulant rodenticides had higher average bait acceptance than acute rodenticides; thus, they tended to perform better overall in efficacy tests. This effect was especially evident in the two rat species, whereas mice tended to readily accept any bait over the laboratory chow. Palatability was low for zinc phosphide bait products (oats and pellets) - a common effect described in numerous sources (Johnston et al. 2005). The low palatability of the zinc phosphide products was likely the direct result of rapid toxicosis and detection of the active ingredient on initial feeding. The slower-acting warfarin and the bromethalin products also had relatively low acceptance, but we could not determine if this was the result of the lower palatability of bait matrix or rodent detection of the active ingredient. Because bait acceptance was based on the consumption of rodenticide bait and laboratory chow, Polynesian rats and house mice might have stopped feeding on the bromethalin products after ingesting a lethal dose and then died; however, $R$. rattus had both relatively low acceptance of this material and low mortality rates: $20 \%$ and $60 \%$ in the 3-day and 7-day trials, respectively. The difethialone product was the only one of those tested that achieved $80 \%$ or higher mortality on all three species in the 3-day choice tests. This product also had generally higher acceptance than other second-generation anticoagulants. The two other secondanticoagulant formulations (brodifacoum and bromadialone) had similar mortality rates but lower acceptance than the difethialone product. The combination of the high toxicity and high palatability resulted in high efficacy for these three products.

The chlorophacinone product performed close to the level of the second-generation rodenticides in efficacy. 
Although this is a first-generation anticoagulant, the excellent bait acceptance resulted in mortality rates that were comparable to the second-generation products. In the two choice trials (Tier 1, 3 days and Tier 2, 7 days), this bait product achieved results that were similar to those of the second-generation rodenticides.

Only three products in the no-choice tests failed to achieve $80 \%$ or greater mortality. In these instances, rodents rejected bait even though no other food was available. $R$. exulans ate only minor amounts of the zinc phosphide pellets. However, the low mortalities for the diphacinone and warfarin products with M. musculus are not as easy to interpret from the overall totals. For these two products, mice often refused to eat the products for several days; thus, they might not have a received a lethal dose. Over the course of the test period, mice ate less and less of these two products.

The diphacinone was the only product that did not have at least $80 \%$ mortality for a single rodent species in the two-choice tests. The warfarin product had similar results but achieved $80 \%$ mortality for roof rats in the 7-day twochoice test. The low efficacy of these two products was likely the result of low overall product toxicity, limited exposure times, and low palatability compared to chlorophacinone and the second-generation anticoagulants.

Our primary conclusion from the results of this comprehensive test series is that additional products or formulations should be registered for specific application to the rodent management problems of Hawaii and the Pacific Basin to provide an improved array of choices for managers and insurance against the loss or unavailability of particular products. In particular, registration of additional chlorophacinone products should be pursued. Given the unlikely possibility of the development of new chemical rodenticides, choices for future research are probably limited to the materials we examined with a few additional options among nationally registered materials, recognizing the trend toward increased regulatory constraints placed on the use of second-generation anticoagulants. Second, we see a continuing need to examine ways to improve the efficiency of using these materials in broad-scale field applications, recognizing the myriad concerns with potential effects on nontarget wildlife and the difficulties of avoiding the land/ocean interface in mechanized applications in Hawaii and other island ecosystems.

Acknowledgments This research was funded by the Hawaii Invasive Species Council, 1151 Punchbowl Street, Room 325, Honolulu, HI 96813 as National Wildlife Research Center Protocol QA-1344. Institutional Animal Care and Use Committee approval was received February 10, 2006. We are grateful to William W. Jacobs and John Eisemann for many helpful comments on data analysis and interpretation; to the manufacturers that provided test materials; and to Mark E. Tobin, former Hawaii Field Station Leader, who developed much of the original technical background for our work. We are also grateful to Catherine Swift and Peter Dunlevy for helpful discussions of rodenticide use in rodent eradication for bird conservation, to Gary $\mathrm{W}$. Witmer for suggesting procedures to minimize the numbers of animals needed and for providing review comments, and to an anonymous reviewer whose insightful comments greatly improved the article. We thank Michael W. Fall for help with literature review, discussion of test results, and editorial assistance.

\section{References}

Ashton AD, Jackson WB, Peters H (1987) Comparative evaluation of $\mathrm{LD}_{50}$ values for various anticoagulant rodenticides. In: Richards CGJ, Ku TY (eds) Control of mammal pests. Taylor \& Francis, London, pp 187-197

Atkinson IAE (1985) The spread of commensal species of Rattus to oceanic islands and their effects on island avifaunas. In: Moors PJ (ed) Conservation of island birds. International Council for Bird Preservation, pp 35-81

Caut S, Casanovas JG, Virgos E, Lozano J, Witmer GW, Courchamp F (2007) Rats dying for mice: modelling the competitor release effect. Austral Ecol 32:858-868

Cherry LD, Gunnoe MD, Vanlier RBL (1982) The metabolism of bromethalin and its effects on oxidative phosphorylation and cerebrospinal fluid pressure. Toxicologist 2:108

Drummond DC, Rennison BD (1973) The detection of rodent resistance to anticoagulants. Bull World Health Organ 48(2):239-242

Endepols S, Prescott CV, Klemann N, Buckle AP (2007) Susceptibility to the anticoagulants bromodiolone and coumatetralyl in wild Norway rats (Rattus Norvegicus) from the UK and Germany. Int J Pest Manage 53(4):285-290

EPA (2008) Risk mitigation decision for ten rodenticides. Office of Pesticides and Toxic Substances, US Environmental Protection Agency, Washington, DC

Fall MW (1977) Rodents in tropical rice. College of Agriculture Tech. Bull. No. 36, University of the Philippines at Los Baños, Philippines

Fall MW (1982) Agricultural development and the ecology of rodent control. In: UNITAR conference on alternate strategies for desert development and management, vol 2. Pergamon Press, New York, pp 443-451

Hadler M, Buckle A (1992) Forty-five years of anticoagulant rodenticides: past, present, and future trends. Proc Vertebr Pest Conf 15:149-155

Howald GR, Faulkner KR, Tershy B, Keitt B, Gellerman H, Creel EM, Grinnel M, Ortega S, Croll, DA (2005) Eradication of black rat from Anacapa Island: biological and social considerations. In: Garcelon, DK, Schwemm CA (eds) Proceedings of the California islands symposium 6. Institute for Wildlife Studies, Arcata, CA, pp 299-312

Howald G, Donlan CJ, Galván JP, Russell J, Parkes J, Samaniego A, Wang Y, Veitch D, Genovesi P, Pascal M, Saunders A, Tershy B (2007) Invasive rodent eradication on islands. Conserv Biol 21:1258-1268

Jackson WB, Kaukeinen DE (1972) Resistance of wild Norway rats in North Carolina to warfarin rodenticide. Science 176:1343-1344

Jacobs W (1994) Pesticides federally registered for control of terrestrial vertebrate pests. In: Hygnstrom S, Timm R, Larson G (eds) Prevention and control of wildlife damage. University of Nebraska, Cooperative Extension Service, Lincoln, NE, pp G1-G22

Johnston JJ, Nolte DL, Kimball BA, Perry KR, Hurley JC (2005) Increasing acceptance and efficacy of zinc phosphide rodenticide 
baits via modification of the carbohydrate profile. Crop Protect 24:381-385

Linder G, Joermann G (2001) Assessing hazard and risk of chemical exposures to wild mammals: food chain analysis and its role in ecological risk assessment. In: Shore RF, Rattner BA (eds) Ecotoxicology of wild mammals. Wiley, NY, pp 635-670

Park BK, Lecka JB (1982) A comparison of vitamin K antagonism by warfarin, difenacoum and brodifacoum in the rabbit. Biochem Pharmacol 31:3635-3639

Pelz HJ, Hänisch D, Lauenstein G (1995) Resistance to anticoagulant rodenticides in Germany and future strategies to control Rattus norvegicus. Pestic Sci 43:61-67

Pelz HJ, Rost S, Hünerberg M, Fregin A, Heiberg A, Baert K, MacNicoll AD, Prescott CV, Walker A, Oldenburg J, Müller CR (2005) The genetic basis of resistance to anticoagulants in rodents. Genetics 170:1839-1847

Quy RJ, Cowan DP, Morgan C, Swinney T (1996) Palatability of rodenticide baits in relation to their effectiveness against farm populations of the Norway rat. Proc Vertebr Pest Conf 17: 133-138

Schneider BA, Hitch RK (1982) Suggested performance standards. In: Pesticide assessment guidelines. US Environmental Protection Agency, Washington, DC, p 309

Spurr EB, Foote D, Perry CF, Lindsey GD (2003) Efficacy of aerial broadcast application of baits containing $0.005 \%$ diphacinone in reducing rat populations in Hawaiian forests. Pacific Island
Ecosystems Research Center, US Geological Survey, Washington, DC

Stone W, Okoniewski J, Stedelin J (1999) Poisoning of wildlife with anticoagulant rodenticides in New York. J Wildl Dis 35:187-193

Sugihara RT (1997) RANDSEL: randomly selecting and assigning animals to treatment groups. Wildl Soc Bull 25:183-184

Swift CE (1998) Laboratory bioassays with wild-caught black and Polynesian rats to determine minimum amounts of Ramik Green (0.005\% diphacinone) and exposure times for field broadcast applications in Hawaii, MS thesis, University of Hawaii, Honolulu

Thijssen HHW (1995) Mouse killer (warfarin)-based rodenticides: mode of action and mechanism of resistance. Pestic Sci 43:73-78

Tomich PQ (1986) Mammals in Hawaii, 2nd edn. Bishop Museum Press, Honolulu

Veitch CR, Clout MN (eds) (2002) Turning the tide: the eradication of invasive species. Invasive Species Specialist Group, Species Survival Commission, World Conservation Union, Gland, Switzerland

Witmer GW, Campbell EW, Boyd F (1998) Rat management for endangered species protection in the U.S. Virgin Islands. Proc Vertebr Pest Conf 18:281-286

Witmer GW, Boyd F, Hillis-Starr Z (2007) The successful eradication of introduced roof rats (Rattus rattus) from Buck Island using diphacinone, followed by an irruption of house mice (Mus musculus). Wildl Res 34:108-115 